Al-Huquq: Journal of Indonesian Islamic Economic Law, 2 (1), 2020: 98 - 113

ISSN: 2715-0003; E-ISSN 2714-5514

DOI: http://dx.doi.org/10.19105/al\%20huquq.v1i1.2818

\title{
Telaah Gharar, Riba, dan Maisir dalam Perspektif Transaksi Ekonomi Islam
}

\author{
Rudiansyah \\ (Institut Agama Islam Negeri Madura Jl. Raya Panglegur Km. 4 \\ Pamekasan 69371)
}

\begin{abstract}
Abstrak:
Manusia dengan kodratnya sebagai makhluk sosial tentu tidak akan pernah terlepas dengan kebutuhan-kebutuan ekonomi dari pihak lain untuk melangsungkan hidupnya. Namun sebagai pemeluk agama Islam yang menyandarkan segala aktifitas kehidupan sehari-sehari kepada ketentuan-ketentuan hukum Islam sebagaimana telah ditetapkan dalam sumber utama hukum Islam yaitu al-Qur'an, Sunnah, Ijma' dan Qiyas, maka sudah seyogyanya bagi masyarakat muslim di dunia dan di Indonesia khususnya untuk menghindari ragam transaksi untuk memenuhi kebutuhan ekonominya yang terindikasi mengandung gharar, riba, dan maisir. Berdasar hal tersebut, maka perlu kiranya menelaah lebih dalam terkait dengan keharaman gharar, riba dan maisir perspektif ekonomi Islam. Adapun hasil telaah menemukan bahwa gharar, riba dan maisir merupakan hal-hal yang tidak diperbolehkan dalam syari'at Islam. Oleh karena itu, merupakan sesuatu yang baik untuk kita sebagai para pelajar abadi memahaminya dan mengamalkannya dalam kehidupan yang fana ini. (Man with his nature as a social creature certainly will never be detached from the needs of economic blindness from other parties to establish his life. But as a religion of Islam that is in terms of all activities daily life to the provisions of Islamic law as stipulated in the main source of Islamic law is theQur'an, Sunnah, ijma ' and qiyas, so it should be for Muslim communities in the world and in Indonesia in particular to avoid various transactions to fulfill its economic needs that are indicative of Gharar, riba, and Maisir. Based on this, it is necessary to study more in relation to the fragrance of Gharar, Riba and maisir of the Islamic economic perspective. The results of the study found that Gharar, riba and Maisir are things that are not allowed in
\end{abstract}

email koresproden: rudasnata@gmail.com

https://creativecommons.org/licenses/by-nc/4.0/

Copyright (c) 2019 by al-huquq. All Right Reserved 
Shari'ah Islam. Therefore, it is a good thing for us as enduring learners to understand it and to practice it in this mortal life.)

\section{Kata Kunci:}

Gadai Tanah; Kurs Harga Emas; Hukum Islam; Desa

Plakpak

\section{Pendahuluan}

Manusia sebagai makhluk ciptaan Allah Swt. adalah makhluk sosial, maksudnya manusia tidak bisa berdiri sendiri tanpa berinteraksi dengan orang lain yang kemudian disebut dengan hidup bermasyarakat. Salah satu hubungan interaksi antar sesama manusia dapat dijumpai dalam kegiatan ekonomi atau bermuamalah. ${ }^{1}$ Kegiatan ekonomi atau muamalah merupakan kegiatan transaksi harta benda yang dilakukan manusia berdasarkan ketentuanketentuan umum yang ada dalam syara' seperti larangan gharar, maysir dan riba, ${ }^{2}$

Bisnis konvensional (non syariah) modern sekarang ini pada umumnya mengandung tiga unsur yang dilarang dalam ideologi perekonomian Islam, yakni gharar, maisir dan riba. Hal ini terjadi tidak lepas dari realitas trend perkembangan bisnis konvensional dan belum meluasnya kesadaran serta cakupan layanan perekonomian berbasis perekonomian Islam. Bank Muamalat Indonesia (BMI) adalah bank pertama murni syariah di Indonesia yang secara prinsip semua produk utamanya baik pada layanan produk Strategi Pembiayaan (deposits funds) maupun produk pembiayaan (financing) berbasis sistem Islam (bagi hasil). BMI berupaya menerapkan aspek ideologi ekonomi Islam yang secara konsisten menghindari gharar, maysir dan riba.

Jadi untuk setiap individu ummat Islam diwajibkan untuk melakukan pencitraan positif terhadap dirinya, orang lain, serta lingkungannya. Sehingga masing-masing individu bertanggungjawab

\footnotetext{
${ }^{1}$ Masduha Abdurrahman, Pengantar dan Asas-asas Hukum Perdata Islam "Fiqh Muamalah", cet. Ke-1, (Surabaya: Central Media,1992), h. 74.

${ }^{2}$ Muhammad, Lembaga-lembaga Keuangan Umat Kontemporer, (Yogyakarta: UII Press,2000), h. 2.
} 
atas kondisi dan situasi yang mengelilinginya. Keberadaan lingkungan sosial yang baik dan damai, kondisi ekonomi masyarakat yang sejahtera, dan situasi politik yang aman merupakan bagian dari ibadah yang dapat dilakukan oleh ummat Islam yang merupakan bentuk penghambaan kepada Allah Swt.

Salah satu ibadah tersebut adalah menciptakan kesejahteraan masyarakat dengan melakukan kegiatan ekonomi. Urgensi ekonomi tidak dapat diabaikan atau dipandang sebelah mata. Kegiatan ekonomi memegang peranan vital untuk menciptakan masyarakat yang sejahtera, adil dan makmur. Islam mengajarkan dalam sistem ekonomi ummatnya, didasarkan pada nilai-nilai keadilan yang harus ditegakkan, dan menjadi prinsip pokok untuk melakukan kegiatan ekonomi. Setiap kegiatan ekonomi harus mengandung unsur manfaat serta tidak melakukan penganiayaan terhadap dirinya dan orang lain, sehingga kegiatan ekonomi dapat menciptakan kesejahteraan masyarakat secara merata. Melakukan kegiatan ekonomi tidak diperbolehkan dilakukan apabila mengandung unsur gharar, maysir dan riba ataupun mengambil hak-hak milik orang lain dengan caracara bathil.

\section{Gharar}

Definisi gharar secara bahasa adalah bahaya, dan taghrir yaitu membawa diri pada sesuatu yang membahayakan. Dalam Kontrak muamalah bisnis perdagangan syariah melarang adanya Gharar dalam setiap transaksinya. Gharar ini dapat diartikan sebagai suatu ketidakjelasan atau bahaya. ${ }^{3}$ Sedangkan makna secara istilah fiqih gharar mempunyai tiga definisi. Pertama, gharar khusus berlaku pada sesuatu yang hasilnya tidak jelas, dapat atau tidak dapat, sebagaimana ungkapan Ibnu 'Abidin, Gharar adalah syak atau keraguan pada apakah komoditi tersebut ada atau tidak ada. Kedua, gharar khusus pada komoditi yang tidak diketahui spesifikasinya. Berkata Ibnu Hazm, gharar pada bisnis yaitu sesuatu dimana pembeli tidak tahu apa yang dibeli, atau pedagang tidak tahu apa yang dijual. Ketiga, gharar mengandung dua makna tersebut diatas.

\footnotetext{
3 Muhammad Yusuf Saleem, 2013, Islamic Commercial Law, John Wiley \& Sons Singapore. Hlm. 3.
} 
Berkata As-Sarhsy," Gharar adalah sesuatu yang aqibatnya tidak jelas. Pendapat ini yang diyakini oleh mayoritas ulama.

Gharar berkaitan juga dengan kontrak jual beli dimana terdapat ketidakjelasan atau ambigu dalam substansi isi perjanjiannya atau objeknya. ${ }^{4}$ Berdasarkan penjelasan pasal 2 ayat 3 peraturan Bank Indonesia No. 7/46/PBI/2005 tentang akad penghimpunan dan penyaluran dana bagi bank yang melaksanakan kegiatan usaha berdasarkan prinsip syariah menjelaskan bahwa gharar merupakan transaksi yang mengandung tipuan dari salah satu pihak sehingga pihak yang lain dirugikan. ${ }^{5}$ Contoh: yaitu transaksi jual beli yang mengandung gharar adalah Abdi berencana membeli perkebunan jambu milik Anton. Namun, Anton memberikan informasi bahwa ia hanya menjual biji jambu di perkebunan miliknya seluas 2 ha yang dapat dipanen sekitar 3 bulan lagi. Dan, Abdi menyepakati bahwa saat ini ia akan membeli jambu di perkebunan milik Anton yang dapat dipanen sekitar beberapa kemudian lagi dan membayar sejumlah uang seketika kontrak disepakati. Dalam transaksi ini mengandung gharar karena objek jual belinya mengandung ketidakjelasan atau ambigu, yakni apakah Abdi membeli jambu atau biji jambu yang tidak jelas ukuran, jenis, dan beratnya.

Dari sisi lain gharar juga ada yang kadarnya sedikit, sedang dan berat. Oleh karena itu sebagian ulama mendefinisikan gharar yaitu segala sesuatu yang diyakini adanya, tetapi diragukan kesempurnaannya (Mukhtar Shihah). Contohcontoh berikut termasuk gharar dari sisi ini: Menjual buah sebelum layak di petik, menjual janin pada induknya, menjual ikan pada tempat pemancingan atau kolam ikan dengan cara dipancing atau dijaring dll.

\section{Dalil - dalil Pengharaman Gharar}

1. Al-Qur'an Surat Al-Baqarah ayat 188:

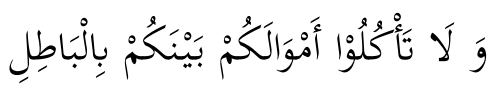

\footnotetext{
4 Ibid.

5 Trisadini P. Usanti, Abd. Shomad, Ari Kurniawan, 2013, Absorpsi hukum Islam pada akad pembiayaan di bank Syariah, Lutfansah Mediatama, Surabaya.Hlm. 10.
} 
Artinya: "Dan janganlah sebagian kamu memakan harta sebagian dari yang lain diantara kamu dengan yang batil."(QS. Al-Baqarah: 188)

2. Al-Qur'an Surat An-Nisa' ayat 29

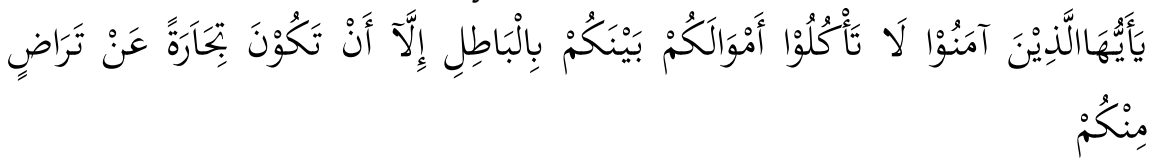

Artinya :"Hai orang-orang yang beriman, janganlah kamu saling memakan harta sesamamu dengan jalan batil kecuali dengan jalan perniagaan yang berlaku suka sama suka diantara kamu." (Q.S. AnNisa : 29)

3. Hadis Riwayat Muslim

$$
\text { الغرر بن هريرة قال فهى رسول الله صلى الله عليه و سلم عن بيع اللحصاة و عن بيع }
$$

Artinya : Dari Abi Hurairah berkata : rasullulah telah melarang jual beli hasah dan jual beli gharar. (HR. Muslim)

4. Hadis Riwayat Ibnu Majah

$$
\text { عن ابن عباس قال هى رسول الله صلى الله عليه و سلم عن بيع الغرر }
$$

Artinya: Dari Ibnu Abbas berkata : Rasullulah saw telah melarang jual beli gharar (HR. Ibnu Majah)

\section{Maisir}

Kata Maisir dalam bahasa Arab arti secara harfiah adalah memperoleh sesuatu dengan sangat mudah tanpa kerja keras atau mendapat keuntungan tanpa bekerja. Merupakan hal yang mengandung unsur judi, taruhan, atau permainan beresiko. ${ }^{6}$ Istilah lain yang digunakan dalam al-Quran adalah kata 'azlam ' yang berarti praktek perjudian.

Secara bahasa Maisir bisa dimaknakan dalam beberapa kalimat : Gampang/mudah, orang yang kaya dan wajib. Secara

\footnotetext{
${ }^{6}$ Ascarya, 2013, Akad\&Produk Bank Syariah, PT Raja Grafindo Persada (Ed.1. Cet
} 4), Jakarta. Hlm. 20. 
istilah, Maisir adalah setiap Mu'amalah yang orang masuk kedalamnya dan dia mungkin rugi dan mungkin beruntung. Kalimat "mungkin rugi dan mungkin untung", juga ada dalam Mu'amalat jual beli, sebab orang yang berdagang mungkin untung mungkin rugi. Namun Mu'amalat jual beli ini berbeda dengan Maisir, seorang pedagang bila mengeluarkan uang maka ia memperoleh barang dan dengan barang itu ia bermu'amalat untuk meraih keuntungan walaupun mungkin ia mendapat kerugian, tapi Maisir, begitu seseorang mengeluarkan uang maka mungkin ia rugi atau tidak dapat apapun dan mungkin ia beruntung.

Ini definisi Maisir dalam istilah ulama, walaupun sebagian orang mengartikan Maisir ini ke dalam bahasa Indonesia dengan pengertian sempit, yaitu judi. Judi dalam terminologi agama diartikan sebagai "suatu transaksi yang dilakukan oleh dua pihak untuk kepemilikan suatu benda atau jasa yang menguntungkan satu pihak dan merugikan pihak lain dengan cara mengaitkan transaksi tersebut dengan suatu tindakan atau kejadian tertentu". Contoh maysir yaitu dalam suatu transaksi adalah Evi membeli sebuah tiket lotere sebesar seribu rupiah per lembarnya dengan harapan akan memenangkan lotere tersebut dan mendapatkan hadiah dari lotere itu. Tiket lotere tersebut berhadiah uang tunai senilai 1 Milyar rupiah.

Prinsip berjudi adalah terlarang, baik itu terlibat secara mendalam maupun hanya berperan sedikit saja atau tidak berperan sama sekali, mengharapkan keuntungan semata (misalnya hanya mencoba-coba) di samping sebagian orang-orang yang terlibat melakukan kecurangan, kita mendapatkan apa yang semestinya kita tidak dapatkan, atau menghilangkan suatu kesempatan. Melakukan pemotongan dan bertaruh benar-benar masuk dalam kategori definisi berjudi.

Judi pada umumnya (maisir) dan penjualan undian khususnya (azlam) dan segala bentuk taruhan, undian atau lotre yang berdasarkan pada bentuk-bentuk perjudian adalah haram di dalam Islam. Rasulullah s.a.w melarang segala bentuk bisnis yang mendatangkan uang yang diperoleh dari untung-untungan, spekulasi dan ramalan atau terkaan (misalnya judi) dan bukan diperoleh dari bekerja. 
Rudiansyah

\section{Dalil - dalil Pengharaman Maisir :}

Terdapat beberapa dalil yang menjadi dasar atas pengharaman maisir, di antaranya adalah firman Allah Subhanahu wa Ta'ala dalam surat Al-Ma'idah ayat 90-91:

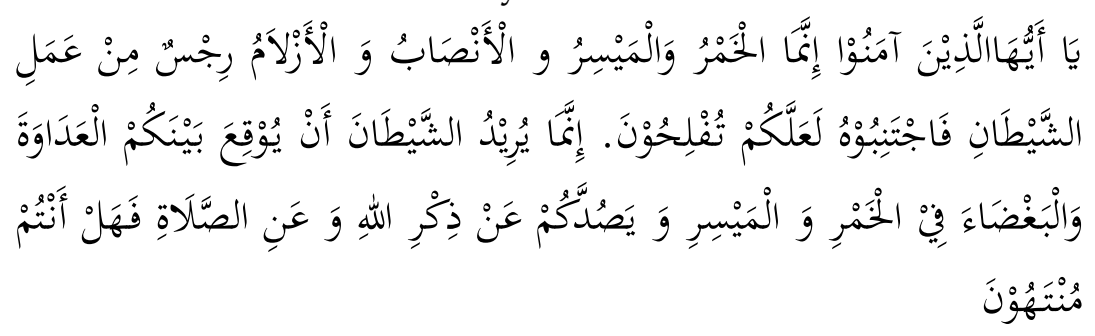

Artinya: "Hai orang-orang yang beriman, sesungguhnya (meminum) khamar, maisir, (berkorban untuk) berhala, mengundi nasib dengan panah, adalah perbuatan keji termasuk perbuatan syaitan. Maka jauhilah perbuatan-perbuatan itu agar kamu mendapat keberuntungan. Sesungguhnya syaitan itu bermaksud hendak menimbulkan permusuhan dan kebencian di antara kamu lantaran (meminum) khamar dan berjudi itu, dan menghalangi kamu dari mengingat Allah dan sembahyang; maka berhentilah kamu (dari mengerjakan pekerjaan itu)". (QS. Al-Ma idah : 90-91)

Selain firman Allah di atas, terdapat pula hadits Abu Hurairah radhiyallahu 'anhu riwayat Al-Bukhary dan Muslim, Nabi shollallahu 'alaihi wa 'ala alihi wa sallam bersada :

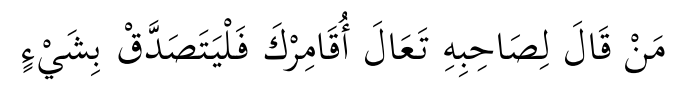

Artinya:"Siapa yang berkata kapada temannya : "Kemarilah saya berqimar denganmu", maka hendaknya ia bershodaqoh." (HR. Bukhari-Muslim)

Qimar menurut sebagian ulama sama dengan maisir, dan menurut sebagian ulama lain qimar hanya pada mu'amalat yang berbentuk perlombaan atau pertaruhan. Dan hadits di atas menunjukan haramnya maisir/qimar dan ajakan melakukannya dikenakan kaffarah (denda) dengan bershodaqoh. Dan tidak ada perselisihan pendapat di kalangan para 'ulama tentang haramnya maisir. 
"Diriwayatkan oleh Abdullah bin Omar bahwa Rasulullah s.a.w. melarang berjualbeli yang disebut habal-al-habla semacam jual beli yang dipraktekkan pada zaman Jahiliyah. Dalam jual beli ini seseorang harus membayar seharga seekor unta betina yang unta tersebut belum lahir tetapi akan segera lahir sesuai jenis kelamin yang diharapkan ".

"Diriwayatkan oleh beberapa sahabat Nabi, termasuk Jabir, Abu Hurairah, Abu Said Khudri, Said bin Al Musayyib dan Rafiy bin Khadij bahwa Rasulullah s.a.w. melarang transaksi muzabanah dan muhaqalah".

Kedua jenis bisnis transaksi diatas sangat merakyat pada zaman sebelum Islam. Muzabanah adalah tukar menukar buah yang masih segar dengan yang sudah kering dengan cara bahwa jumlah buah yang kering sudah dapat dipastikan jumlahnya sedangkan buah yang segar ditukarkan hanya dapat ditebak karena masih berada di pohon. Sama halnya dengan muhaqalah yaitu penjualan gandum ditukar dengan gandum yang masih ada dalam bulirnya yang jumlahnya masih ditebak-tebak.

Disebabkan karena kejahatan judi itu lebih parah dari pada keuntungan yang diperolehnya, maka dalam Al-Qur'an, Allah swt sangat tegas dalam melarang maisir (judi dan semacamnya) sebagaimana ayat berikut:

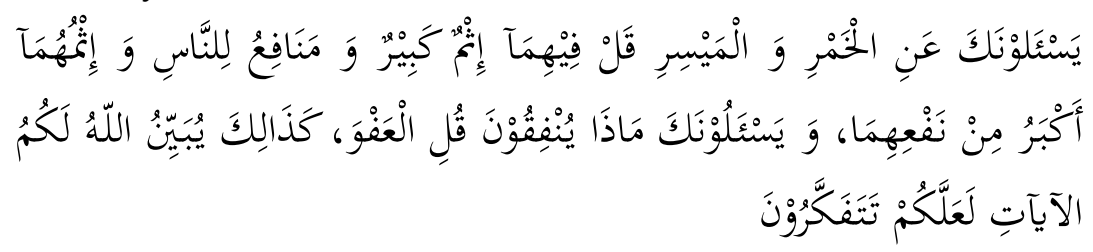

Artinya: "Mereka akan bertanya kepadamu tentang minuman keras dan judi, katakanlah: pada keduanya terdapat dosa besar dan manfaat bagi manusia. Tetapi dosanya lebih besar dari pada manfaatnya..." (QS. Al Baqarah 2:219).

Ayat di atas secara tegas menunjukkan keharaman judi. Selain judi itu rijs yang berarti busuk, kotor, dan termasuk perbuatan setan, ia juga sangat berdampak negatif pada semua aspek kehidupan. Mulai dari aspek ideologi, politik, ekonomi, social, moral, sampai budaya. Bahkan, pada gilirannya akan merusak sendi-sendi kehidupan berbangsa dan bernegara. Sebab, setiap perbuatan yang 
melawan perintah Allah SWT pasti akan mendatangkan celaka. Karena itu merupakan perbuatan setan, maka wajar jika kemudian muncul upaya-upaya untuk menguburkan makna judi. Sebab salah satu tugas setan, yang terdiri dari jin dan manusia, adalah mengemas sesuatu yang batil (haram) dengan kemasan bisnis yang baik dan menarik, atau dengan nama-nama yang indah, cantik, dan memiliki daya tarik, hingga tampaknya seakan-akan halal. Allah SWT berfirman dalam surat Al-An'am ayat 112:

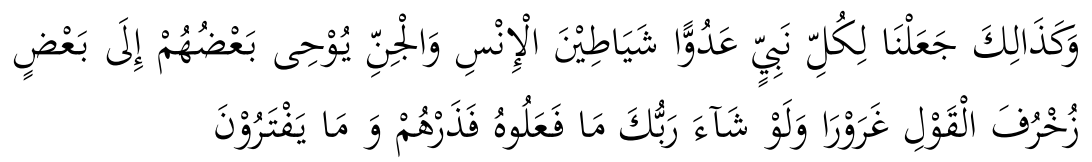

Artinya: "Dan demikianlah kami jadikan bagi tiap-tiap nabi itu musuh, yaitu setan-setan (dari jenis) manusia dan (dari jenis) jin. Sebagian mereka membisikkan kepada sebagian yang lain perkataanperkataan yang indah-indah untuk menipu manusia" (QS. AlAn`am: 112)

Juga perhatikan firman-Nya dalam surat Al-An'am ayat 43:

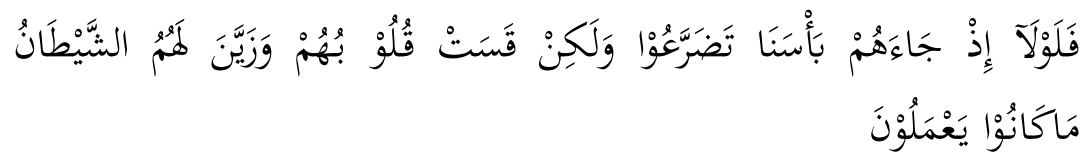

Artinya: "Dan setan pun menampakkan kepada mereka kebagusan keindahan apa yang selalu mereka kerjakan" (QS. Al-An'am: 43)

Rasulullah SAW juga mensinyalir perbuatan setan yang demikian itu sebagai, "Surga itu dikelilingi oleh sesuatu yang tidak menyenangkan, sedangkan mereka (setan) dikelilingi oleh sesuatu yang menyenangkan". (HR. Bukhari - Muslim).

\section{Riba}

Riba dapat dikatakan sebagai penambahan sejumlah harta yang bersifat khusus.7 Ibnu Rifeah mengemukakan bahwa riba adalah nilai tambah dalam transaksi emas, perak dan seluruh jenis makanan, dan dapat pula dikatakan bahwa riba mengambil harta tertentu selain

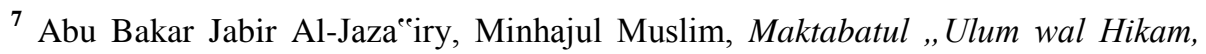
Madinah (cet. 66 tahun 1419 H). Diterjemahkan oleh Musthofa „Aini, dkk, 1998, Panduan Hidup Seorang Muslim. PT. Megatama Sofwa Pressindo, Jakarta. Hlm. 560.
} 
harta yang dipinjam. ${ }^{8}$ Disamping itu, riba juga didefinisikan oleh syafieiyah yang merupakan akad atas iwadh (penukaran) tertentu yang tidak diketahui persamaannya dalamm ukuran syara' pada waktu akad atau dengan mengakhirkan (menunda) kedua penukaran tersebut atau salah satunya. ${ }^{9}$

Menurut etimologi, riba berarti الزّيادة (tambahan), seperti arti kata riba pada ayat:

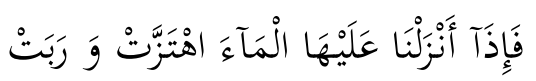

Artinya : "Kemudian apabila kami turunkan air diatasnya, hiduplah bumi itu dan suburlah." (Al-Hajj : 5)

ini.

Menurut terminologi, ulama fiqih mendefinisikannya berikut

1. Ulama Hanabilah

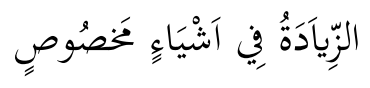

Artinya : "pertambahan sesuatu yang dikhususkan."

2. Ulama Hanafiyah

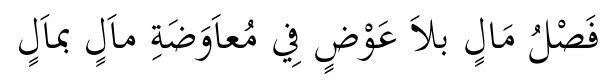

Artinya: "Tambahan pada harta pengganti dalam pertukaran harta dengan harta."

Contoh riba dalam suatu transaksi adalah adanya tambahan dalam suatu hutang piutang. Utand meminjam uang sebesar Rp 100.000,- (seratus ribu rupiah) kepada Habib, namun Habib memberikan syarat apabila hutang ingin meminjan uang sebesar Rp. 100.000,- (seratus ribu rupiah) maka ia harus mengembalikan Rp. 110.000,- (seratus sepuluh ribu rupiah) pada bulan berikutnya. Dalam transaksi ini terdapat suatu tambahan sebesar Rp. 10.000,- (sepuluh ribu rupiah), sehingga tambahan ini yang dinamakan dengan riba.

\footnotetext{
8 Wahbah Zuhaili, 2008, Al Fiqhu Asy-Syafi"i Al Muyassar, Darul Fikr, Beirut. Diterjemahkan oleh Muhammad Afifi, Abdul Hafiz, 2010, Fiqh Imam Syafi"i 2. Almahira, Surabaya, Hlm. 37.

9 Abi Al-Abbas ${ }^{e e}$ Ahmad Ar-Ramli, 2004, Nihayah Al-Muhtaj, Juz 3, Dar Al-Fikr, Beirut. Hlm. 424.
} 
Rudiansyah

\section{Dalil Keharaman Riba}

Riba diharamkan berdasarkan Al-Qur'an, Sunah, dan Ijma' :

1. Al-Qur'an

Sebagaimana firman Allah SWT. dalam surah Al

Baqarah ayat 275:

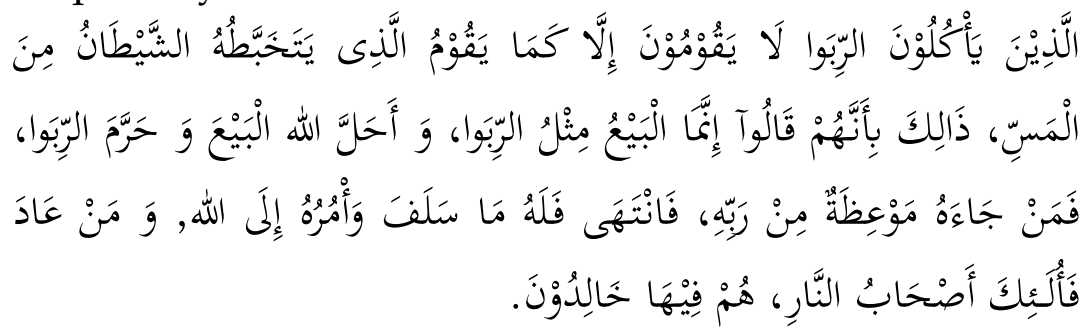

Artinya: "Orang-orang yang makan (mengambil) riba tidak dapat berdiri melainkan seperti berdirinya orang yang kemasukan syaitan lantaran (tekanan) penyakit gila. Keadaan mereka yang demikian itu, adalah disebabkan mereka berkata (berpendapat), sesungguhnya jual beli itu sama dengan riba, padahal Allah telah menghalalkan jual beli dan mengharamkan riba. Orang-orang yang telah sampai kepadanya larangan dari Tuhannya, lalu terus berhenti (dari mengambil riba), maka baginya apa yang telah diambilnya dahulu (sebelum datang larangan); dan urusannya (terserah) kepada Allah. Orang yang kembali (mengambil riba), maka orang itu adalah penghunipenghuni neraka; mereka kekal di dalamnya."

Selain itu, firman Allah dalam surah Al-Baqarah ayat 278-279 :

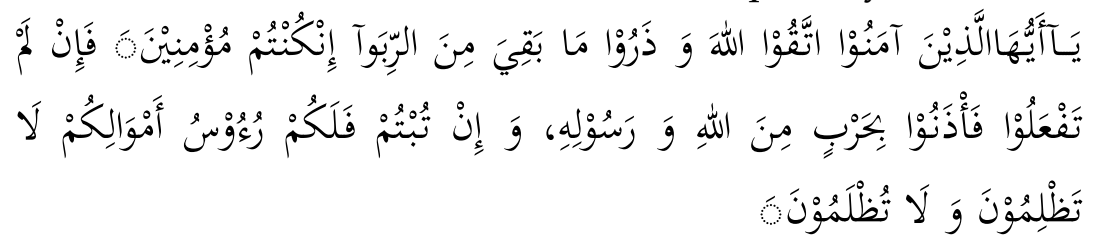

Artinya: "Hai orang-orang yang beriman, bertakwalah kepada Allah dan tinggalkan sisa riba (yang belum dipungut) jika kamu orangorang yang beriman. Maka jika kamu tidak mengerjakan (meninggalkan sisa riba), maka ketahuilah, bahwa Allah dan RasulNya akan memerangimu. Dan jika kamu bertaubat (dari pengambilan riba), maka bagimu pokok hartamu; kamu tidak menganiaya dan tidak (pula) dianiaya." 


\section{As-Sunah}

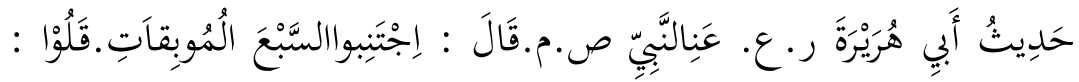

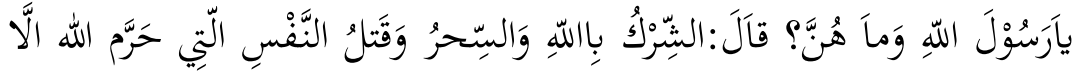

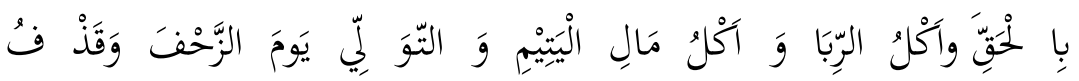

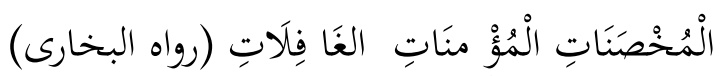

Artinya: "Abu Hurairah r.a berkata bahwa Nabi SAW. bersabda, Tinggalkanlah tujuh dosa yang dapat membinasakan. Sahabat bertanya. Apakah itu, ya itu, ya Rasulallah?' 'Jawab Nabi, (1) syirik (memperskutuan Allah); (2) Berbuat sihir (tenung); (3) Membunuh jiwa yang diharamkan Allah, kecuali yang hak; (4) Makan harta riba; (5) Makan harta anak yatim; (6) Melarikan diri dari perang jihad pada saat berjuang; dan (7) Menuduh wanita mukminat yang sopan (berkeluarga). Dengan tuduhan zina. (HR.Bukhari)

$$
\begin{aligned}
& \text { روي عن ابن مسعود بِّئّى قال : لعن رسول الله صلى الله عليه و سلم، آكل } \\
& \text { الربا و مؤكله و شاهده و كاتبه. (رواه أبوداود و غيره) }
\end{aligned}
$$

Artinya : "Diriwayatkan oleh Ibn Mas'ud r.a bahwa Rasulullah SAW. telah melaknat pemakan riba, yang mewakilinya, saksinya, dan penulisnya. "

3. Ijma'

Seluruh ulama sepakat bahwa riba diharamkan dalam islam.

\section{Macam-Macam Riba}

\section{Menurut Jumhur Ulama}

Jumhur ulama membagi riba dalam dua bagian, yaitu riba fadhl dan riba nasi'ah.

a. Riba Fadhl

Menurut ulama Hanafiyah, riba fadhl adalah:

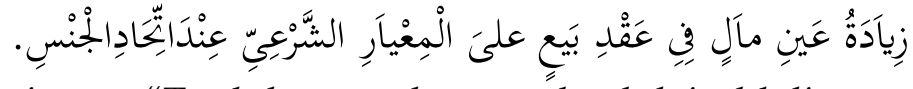

Artinya : "Tambahan zat harta pada akal jual-beli yang diukur dan sejenis." 
Dengan kata lain, riba fadhl adalah jual-beli yang mengandung unsur riba pada barang sejenis dengan adanya tambahan pada salah satu benda tersebut. Oleh karena itu, jika melaksanakan akad jual-beli antarbarang yang sejenis, tidak boleh dilebihkan salah satunya agar terhindar dari unsur riba.

b. Riba Nasi'ah

Menurut ulama Hanafiyah, riba nasi'ah adalah :

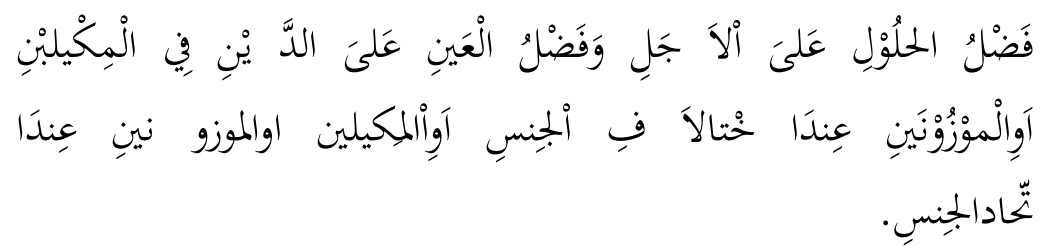

Artinya : "Memberikan kelebihan terhadap pembayaran dari yang ditangguhkan, memberikan kelebihan pada benda disbanding utang pada benda yang ditakar atau ditimbang yang berbeda jenis atau selain dengan yang ditakar dan ditimbang yang sama jenisnya."

Maksudnya, menjual barang dengan sejenisnya, tetapi yang satu lebih banyak, dengan pembayaran diakhirkan, seperti menjual satu kilogram gandum dengan satu setengah kilogram gandum, yang dibayarkan setelah dua bulan. Contoh jual-beli yang tidak ditimbang, seperti membeli satu buah semangka dengan dua buah semangka yang akan dibayar setelah sebulan.

Ibn abbas, usamah Ibn Jaid Ibn arqom, jubair, Ibn jabir, dll. Berpendapat bahwa riba yang diharamkan hanyalah riba nasi'ah pendapat ini didasarkan pada hadist yang diriwayatkan oleh bukhari muslim bahwa Rasulullah SAW bersabda:

$$
\text { لا رِبَّا إلَّا فِي النّسنيْيَة }
$$

Artinya : Tidak ada riba kecuali pada riba nasi'ah."

Ulama lainnya menentang bendapat tersebut dan memberikan dalil-dalil yang menetapkan riba fadl, sedangkan tabi'in sepakat tentang haramnya kedua riba tersebut dan perbedaan pendapatpun hilang. 
Selain itu mereka yang menyatakan bahwa hanya riba nasi'ah yang diharapkan kemungkinan tidak utuh dalam memahami hadits diatas. Asal hadits diatas adalah Nabi Muhammad SAW ditanya tentang pertukaran antara gandum dan sya'ir, emas, dan perak yang pembayarannya diakhirkan, kemudian Nabi Muhammad SAW bersabda "Tidak ada riba kecuali pada riba nasi'ah." Hadits ini lebih tepat diartikan bahwa riba nasi'ah adalah riba terberat dibandingkan dengan riba lainnya. Hal ini sama dengan pernyataan,"Tidak ada ulama didaerah ini kecuali Ahmad." Padahal kenyataanya, juga ada ulama selain ahmad. Hanya saja ahmad merupakan ulama yang paling disegani.

2. Menurut Ulama syafi'iyah

Ulama Syafi'iyah, membagi riba menjadi tiga jenis.

a. Riba fadhl

Riba fadhl adalah jualbeli yang disertai adanya tambahan salah satu pengganti (penukar) dari yang lainnya. Dengan kata lain, tambahan berasal dari penukar paling akhir. Riba ini terjadi pada barang yang sejenis, seperti menjual satu kilogram kentang dengan satu setengah kilogram kentang.

b. Riba Yad

Jual-beli dengan mengakhirkan penyerahan (al-qabdu), yakni bercerai-berai antara dua orang yang akad sebelum timbang terima, seperti menganggap sempurna jual-beli antara gandum dengan sya'ir tanpa harus saling menyerahkan dan menerima di tempat akad. Menurut ulama Hanafiyah, riba ini termasuk riba nasi'ah, yakni menambah yang tampak dari utang.

c. Riba Nasi'ah

Riba Nasi'ah, yakni jual-beli yang pembayarannya diakhirkan, tetapi ditambahkan harganya. Menurut ulama syafi'iyah, riba yad dan riba nasi'ah sama-sama terjadi pada pertukaran barang yang tidak sejenis. Perbedaannya, riba yad mengakhiri pemegang barang, sedangkan riba nasi'ah mengakhiri hak dan ketika akad dinyatakan bahwa waktu pembayaran diakhirkan meskipun sebentar. Al-Mutawalli 
menambahkan, jenis riba dengan riba qurdi (mensyaratkan adanya manfaat). Akan tetapi, Zarkasyi menempatkannya pada riba fadhl.

\section{Kesimpulan} bahwa :

Dari penjelasan di atas, maka penulis dapat menyimpulkan

1. Gharar adalah sesuatu dimana pembeli tidak tahu apa yang dibeli

2. Maisir adalah suatu transaksi yang dilakukan oleh dua pihak untuk kepemilikan suatu benda atau jasa yang menguntungkan satu pihak dan merugikan pihak lain dengan cara mengaitkan transaksi tersebut dengan suatu tindakan atau kejadian tertentu

3. Riba adalah merupakan akad atas iwadh (penukaran) tertentu yang tidak diketahui persamaannya dalamm ukuran syara' pada waktu akad atau dengan mengakhirkan (menunda) kedua penukaran tersebut atau salah satunya.

Gharar, raysir, dan riba merupakan hal-hal yang tidak diperbolehkan dalam syari'at Islam. Oleh karena itu, merupakan sesuatu yang baik untuk kita sebagai para pelajar abadi memahaminya dan mengamalkannya dalam kehidupan yang fana ini.

\section{Daftar Pustaka}

Abi Al-Abbas ${ }^{e e}$ Ahmad Ar-Ramli, Nihayah Al-Muhtaj, Juz 3, Dar AlFikr, Beirut, 2004.

Abu Bakar Jabir Al-Jaza“iry, Minhajul Muslim. Maktabatul „Ulum wal Hikam, Madinah (cet. 66 tahun 1419 H). Diterjemahkan oleh Musthofa "Aini, Lc, Amir Hamzah Fachrudin, Kholif Mutaqin dkk, Panduan Hidup Seorang Muslim. PT. Megatama Sofwa Pressindo, Jakarta.

Ascarya, AkadEProduk Bank Syariah, PT Raja Grafindo Persada (Ed.1. Cet 4), 2013.

Masduha Abdurrahman, Pengantar dan Asas-asas Hukum Perdata Islam

"Figh Muamalah", cet. Ke-1, Surabaya: Central Media,1992. 
Muhammad Yusuf Saleem, Islamic Commercial Law, John Wiley \& Sons Singapore. 2013.

Muhammad, Lembaga-lembaga Keuangan Umat Kontemporer, Yogyakarta: UII Press,2000.

Prof. Dr. H. Rachmat Syafi'i, M.A, Fiqih Mu'amalah, Pustaka Setia, Bandung

Trisadini P. Usanti, Abd. Shomad, Ari Kurniawan, Absorpsi hukum Islam pada akad pembiayaan di bank Syariah, Lutfansah Mediatama, Surabaya, 2013.

Wahbah Zuhaili, Al-Figh Al-Islamiy wa Adillatuh, Juz 4, Dar Al-Fikr (cet. III), Damaskus, 2008. 